\title{
WIEDZA Z ZAKRESU ZAGADNIEŃ PRAWNYCH W PRACY PRACOWNIKA SOCJALNEGO
}

\begin{abstract}
AвSTRACT. Rajewska de Mezer Joanna, Wiedza z zakresu zagadnień prawnych w pracy pracownika socjalnego [Legal Knowledge in the Work of a Social Worker]. Studia Edukacyjne nr 49, 2018, Poznań 2018, pp. 353-372. Adam Mickiewicz University Press. ISSN 1233-6688. DOI: 10.14746/se.2018.49.21

This article raises the problem of the need to equip a social worker with knowledge concerning legal issues useful in assistance activities. Professional knowledge of selected legal problems is necessary in the face of still emerging new situations that create dysfunction for collective life and cause inability in overcoming difficulties by using their own capabilities, competences and resources. Work aimed at supporting and activating a social welfare beneficiary require from a social worker a wide interdisciplinary knowledge, including familiarity with various fields of law. Knowledge in the field of substantive (social law, family law) and procedural law used during work with a beneficiary allows a social worker to conduct the assistance process more effectively. The law-realted problems faced by the social worker who performs statutory tasks are connected to the extent of the regulated problems, constant changeability of legal regulations, their interpretative ambiguity, the necessity of using judicial decisions. It requires appropriate, methodical and purposeful action in the process of educating social workers, which influences the expected efficiency of their work and a sense of safety from a formal point of view.
\end{abstract}

Key words: social work, education of social worker, social welfare beneficiary, social law, effective assistance process

Funkcjonwanie we współczesnym świecie wymaga od jednostki szeregu kompetencji społecznych i profesjonalnych (zawodowych), ciągłego adaptowania się do stale zmieniających się warunków gospodarczych oraz społecznych, powodujących niestabilność sytuacji zawodowej, materialnej, a w efekcie poczucie niepewności o przyszłość. Istotnymi problemami społecznymi w Polsce, w ostatních dwudziestu pięciu latach, stały się spowodowane zmianami organizacyjnymi w zakładach pracy redukcje zatrudnienia i będące ich skutkiem bezrobocie, a w ślad za nimi problemy materialne, uzależnieniowe 
i zdrowotne jednostek, których kompetencje działania okazały się niewystarczające wobec wymogów stawianych im przez współczesny świat.

Pojawianie się generujących dysfunkcję dla życia zbiorowego problemów oraz istotnych rozmiarów potrzeb socjalnych, wynikających z rosnącej liczby osób będących w trudnej sytuacji życiowej, której przezwyciężenie wykracza poza ich własne możliwości, zasoby, kompetencje, wymaga zaingerowania przez osobowe, materialne i instytucjonalne zasoby wsparcia. Celem podejmowanych przez pańtwo działań jest pomoc w rozwiązaniu problemów jednostkowych i grupowych, eliminowanie zagrożeń oraz wsparcie w realizacji zadań życiowych, aspiracji i wartości. Z uwagi na powyższe, współczesne systemy pomocowe opierają się na aktywności państwa (jego wyspecjalizowanych instytucji) oraz solidarności i aktywności poszczególnych jednostek, grup i społeczności ${ }^{1}$.

Problemom tym stawiają czoła pracownicy socjalni, wykonujący w ramach pracy zawodowej zadania ustawowe w zakresie wsparcia osób i rodzin, które nie są w stanie samodzielnie przezwyciężyć problemów, z którymi się zetknęły w swoim życiu. Zakres i multidyscyplinarność problematyki objętej działaniami pomocowymi wymaga od nich szerokiej wiedzy, w tym wiedzy z zakresu prawa. Niniejszy artykuł poświęcony został problemowi wiedzy z dziedziny prawa, jaką powinni mieć świadczący wsparcie klientowi pracownicy socjalni, aby udzielana przez nich pomoc była efektywna i prowadziła do realnego usamodzielnienia beneficjenta. W rozważaniach poniższych zaakcentowano także wielość i różnorodność zagadnień o charakterze prawnym znajdujących się w zainteresowaniu pomocy społecznej, kwestię niestabilności stanu prawnego spowodowaną ciągłymi zmianami przepisów prawa oraz konieczność praktycznego podejścia do procesu kształcenia przyszłych pracowników socjalnych w zakresie problematyki prawnej.

Współcześnie pomoc jednostkom niepotrafiącym samodzielnie przezwyciężać trudnej sytuacji życiowej, w której się znalazły, jest bardzo rozbudowana i odgrywa ważną rolę w działaniach państwa związanych ze sferą socjalną. Przejmowanie przez państwo i podległe mu organy zadań $z$ tego obszaru następowało jednak stopniowo, a system pomocy funkcjonujący w obecnym kształcie tworzył się przez dziesięciolecia. Zakres świadczeń, jakie administracja kieruje do osób potrzebujących wsparcia ze strony społeczeństwa uległ modyfikacji i rozbudowie, a formy ich udzielania zostały rozwinięte. Zaobserwowano również zmiany wobec osób korzystających z różnorodnych form wsparcia ze strony instytucji publicznych².

${ }^{1}$ Z. Woźniak, Praca socjalna a innowacje społeczne - między rutyna i zmiana, Ruch Prawniczy, Ekonomiczny i Socjologiczny, 2016, LXXVIII, 3, s. 208.

2 S. Nitecki, Prawo do pomocy społecznej w polskim systemie prawnym, Warszawa 2008, s. 11-12. 
Wszelkie działania o charakterze pomocowym podejmowane $\mathrm{w}$ procesie wspierania jednostki i rodziny powinny umożliwiać podmiotom objętym wsparciem (jednostce, rodzinie), wyjście z trudnej sytuacji życiowej, z którą nie są $\mathrm{w}$ stanie poradzić sobie $\mathrm{z}$ wykorzystaniem własnych kompetencji, możliwości, zasobów $w^{3}$. Jest to zasada uniwersalna, na której opiera się organizacja i działalność pomocy społecznej nie tylko w Polsce.

W literaturze przedmiotu pomocy społecznej przypisywane są trzy podstawowe cele operacyjne, którym powinno być podporządkowane działanie o charakterze pomocowym. Pierwszy z nich stanowi zaspokojenie podstawowych potrzeb życiowych jednostek i rodzin oraz umożliwienie im bytowania w warunkach odpowiadających godności człowieka. Następnym celem, urzeczywistniającym zasadę pomocniczości, jest działanie zmierzające do życiowego usamodzielnieniu beneficjentów oraz pomocy im w integracji ze środowiskiem. Natomiast ostatnim, podejmowanym $w$ ramach działania pomocy społecznej, jest zapobieganie powstawaniu trudnych sytuacji życiowych stanowiących jedną z przesłanek nabycia pomocy ${ }^{4}$. Działania wobec podmiotów objętych wsparciam mają więc charakter wspierająco-aktywizujący, pomocowy oraz profilaktyczny.

Okoliczności generujące sytuacje trudne, wymagające zaingerowania państwa w życie jednostki, czy grupy (jaką stanowi rodzina), wymienione zostały w art. 7 Ustawy o pomocy społecznej ${ }^{5}$. Związane są one z koniecznością udzielenia pomocy ze względu na stan zdrowia beneficjenta, potrzebę ochrony dziecka i rodziny, trudności w przystosowaniu się do funkcjonowania w społeczeństwie, po okresie przebywania w zakładzie karnym, lub pieczy zastepczej, uzależnienia, czy też sytuacje nagłe i nieprzewidziane ${ }^{6}$. Wymienione przyczyny będące podstawą podjęcia działania pomocowego przez kompetentne organy państwowe mają charakter przykładowy. Nie mamy tu do czynienia z enumeratywnością wyliczenia powodów uruchomienia pomocowej aktywności państwa, co powoduje, że wystąpienie innych

\footnotetext{
${ }^{3}$ Art. 2 Ustawy z 12 marca 2004 r. o pomocy społecznej (DzU z 2017, poz. 1769).

${ }^{4}$ T. Kaźmierczak, Polityka pomocy społecznej wobec rodziny we wspótczesnej Polsce, [w:] Praca socjalna. Pomoc społeczna, red. J. Kwaśniewski, Katowice 1998, s. 249.

${ }^{5}$ W art. 7 Ustawy z 12 marca 2004 r. o pomocy społecznej (DzU z 2017, poz. 1769) wymieniono następujące przyczyny uzasadniające udzielenie beneficjentowi pomocy: ubóstwo, sieroctwo, bezdomność, bezrobocie, niepełnosprawność, długotrwała lub ciężka choroba, przemoc w rodzinie, potrzeba ochrony ofiar handlu ludźmi, ochrona macierzyństwa lub wielodzietności, bezradność w sprawach opiekuńczo-wychowawczych i prowadzenia gospodarstwa domowego, zwłaszcza w rodzinach niepełnych lub wielodzietnych, trudności w integracji cudzoziemców, którzy uzyskali w Rzeczpospolitej Polskiej status uchodźcy lub ochronę uzupełniającą, trudności w przystosowaniu do życia po zwolnieniu z zakładu karnego, skutki alkoholizmu lub narkomanii, ale także wystąpienie zdarzenia losowego i sytuacji kryzysowej, klęski żywiołowej lub ekologicznej.

${ }^{6}$ I. Sierpowska, Prawo pomocy społecznej, Kraków 2006, s. 47.
} 
niż wskazane ustawowo sytuacji nie eliminuje możliwości uzyskania przez beneficjenta wsparcia.

Jako drugi warunek uzyskania pomocy wymieniana jest niemożność samodzielnego przezwyciężenia wyżej wymienionej trudności przez wnioskujacego o pomoc. Ta przesłanka znajduje wyraz w wielu orzeczeniach sądowych w sprawach z zakresu pomocy społecznej. W myśl na przykład orzeczenia Wojewódzkiego Sądu Administracyjnego w Poznaniu, istotą pomocy społecznej jest

(...) pomoc obywatelom w szczególnie dla nich trudnej sytuacji życiowej. Wsparcie to nie ma jednak bynajmniej charakteru obligatoryjnego, lecz zależy od uznania administracyjnego. (...) korzystanie z pomocy społecznej powinno nastąpić dopiero wtedy, gdy nie istnieją inne możliwości zaspokojenia określonej potrzeby ${ }^{7}$.

W innym wyroku sąd orzekł natomiast, iż jednostka może uzyskać pomoc świadczoną przez podmioty działające w systemie pomocy społecznej dopiero wówczas, kiedy wykorzysta swoje uprawnienia, posiadane zasoby i możliwości, przez które należy rozumieć nie tylko sytuację materialną, ale również jej właściwości psychofizyczne, kwalifikacje zawodowe, aktywność w rozwiązywaniu własnych i rodzinnych problemów oraz jej gotowość do współdziałania w tym celu z innymi. Sąd stwierdził także, że przyznający pomoc musi uwzględniać wysokość już przyznanych świadczeń i dokonywać rozdziału środków w taki sposób, aby z pomocy społecznej skorzystała jak największa liczba podopiecznych, gdyż tylko takie postępowanie jest zgodne z zasadami sprawiedliwości społecznej oraz wyrażoną w art. 4 Ustawy o pomocy społecznej ${ }^{8}$ zasadą współdziałania beneficjenta z podmiotem dostarczającym wsparcia9.

Pomoc społeczna ujmowana jest jako metoda zmierzająca do osiągania celów polityki społecznej. Fundament dla podejmowanych działań stanowi zasada pomocniczości, która będąc zasadą konstytucyjną, odwołuje się do samodzielności obywateli i wspólnot w realizowaniu zadań publicz$n_{y c h}{ }^{10}$. Państwo powinno wspierać jednostki, rodziny, które nie są w stanie samodzielnie wykonywać nałożonych na nie zadań. Pomoc ta jednak nie może polegać na podejmowaniu działania w zamian za jednostkę, gdyż prowadzi to do pozbawiania jej kompetencji do działania, a w efekcie do

${ }^{7}$ Orzeczenie Wojewódzkiego Sądu Administracyjnego w Poznaniu z 14 maja 2010 r., sygn. II SA/Po 96/10, (http:/ / orzeczenia.nsa.gov.pl) [dostęp: 10.02.2018].

8 "Osoby i rodziny korzystające z pomocy społecznej są obowiązane do współdziałania w rozwiązywaniu ich trudnej sytuacji życiowej" - art. 4 Ustawy z 12 marca 2004 r. o pomocy społecznej.

9 Wyrok Wojewódzkiego Sądu Administracyjnego w Olsztynie z 5 lutego 2013 r., sygn. II SA/Ol 1290/12 LexPolonica nr 5149485, http:/ / orzeczenia.nsa.gov.pl [dostęp: 10.02.2018].

${ }^{10}$ I. Sierpowska, Ustawa o pomocy społecznej. Komentarz, Warszawa 2007, s. 24. 
zjawiska wyuczonej bezradności ${ }^{11}$. Świadczone wsparcie winno mieć charakter aktywizujący, pobudzający samokreację, ale o czym nie wolno zapomnieć - subsydiarny.

Zasada pomocniczości jest zasadą podstawową, na której powinny opierać się działania podmiotów systemu pomocy społecznej, a więc działania wypełniające ustawowe zadania pracowników socjalnych. Jej znaczenie w aktywności państwa na rzecz jednostki i społeczeństwa rozważane jest od wieków. Idea pomocniczości (subsydiarności) pojawiła się już w rozważaniach starożytnych, na przykład Arystotelesa, a w późniejszych okresach historii nawiązywali do niej Althusius, Mill i Proudhon. Obecny kształt nadały jej encykliki papieskie: Rerum novarum autorstwa Papieża Leona XIII (1891 r.) oraz Quadragesimo anno ${ }^{12}$ Piusa XI (1931 r.).

Zainteresowanie problematyką subsydiarności wzrosło po drugiej wojnie światowej, stanowiąc opozycję wobec zakwestionowanej opiekuńczej roli państwa z jednej strony, a zarazem wskazując kierunki transformacji z drugiej. Idea subsydiarności stała się natomiast hasłem przewodnim integrującej się Europy ${ }^{13}$.

Zasada pomocniczości (subsydiarności) stanowi jedną z podstaw demokratycznego państwa prawa i została wyartykułowana także w Konstytucji $\mathrm{RP}^{14}$. Odwołuje się ona do samodzielności jednostek i wspólnot $\mathrm{w}$ realizowaniu zadań publicznych, dopuszczając ingerencję państwa lub większych wspólnot tylko w sytuacji, kiedy jednostka, czy grupa społeczna, nie jest w stanie samodzielnie, bez wsparcia powołanych do tego podmiotów, wykonać nałożonego na nią zadania ${ }^{15}$.

Należy także pamiętać, że państwo nie może ograniczać inicjatywy obywateli, pozbawiać ich możliwości dokonywania wyboru, czy przejmować

${ }^{11}$ Zjawisko wyuczonej bezradności opisane zostało przez M.E.P. Seligmana w: Helplessness: On Depression, Development, and Death, San Francisco 1992.

${ }_{12}$ Pius XI w Encyklice o odnowieniu ustroju społecznego Quadragesimo Anno akcentuje filozoficzno-moralny aspekt zasady subsydiarności: „Nienaruszalnym i niezmiennym pozostaje owo najwyższe prawo filozofii społecznej: co jednostka $z$ własnej inicjatywy i własnymi siłami może zdziałać, tego jej nie wolno wydzierać na rzecz społeczeństwa; podobnie niesprawiedliwością, szkodą społeczną i zakłóceniem ustroju jest zabieranie mniejszym i niższym społecznościom tych zadań, które mogą spełnić i przekazywanie ich wyższym. Każda akcja społeczna ze swej natury ma charakter pomocniczy; winna pomagać członkom organizmu społecznego, a nie niszczyć ich lub wchłaniać"; Zob.: Pius XI, Encyklika o odnowieniu ustroju społecznego - Quadragesimo Anno, przekł. ks. J. Piwowarczyk, Znak, 1982, 80, s. 42-23.

${ }_{13}$ A. Dobek, Zasada pomocniczości w orzecznictwie Trybunału Konstytucyjnego, Wrocławskie Studia Erazmiańskie, z. II: Państwo - koncepcje i zadania, Wrocław 2008, s. 155-156.

${ }^{14}$ Konstytucja RP z 2 kwietnia 1997 r. (DzU z 1997, nr 78, poz. 483 ze zm.).

${ }^{15} \mathrm{~J}$. Rajewska de Mezer, Rozważania dotyczące aktywizującej roli podmiotów systemu pomocy społecznej, [w:] Animacja w środowisku. O potrzebie kreowania działań lokalnych (teoria a praktyka społeczna), red. K. Segiet, K. Słupska, A. Tokaj, Poznań 2017, s. 240. 
odpowiedzialności za ich działania ${ }^{16}$. Udzielane wsparcie powinno przyjąć charakter korygujący i stanowić tak zwaną "pomoc do samopomocy”. Pomoc w swym założeniu winna być tylko przejściowa i skłaniać do samoaktywizacji, bazując na posiadanym przez jednostkę, rodzinę, czy społeczność potencjale i świadmości deficytów, częstokroć diagnozowanych i uświadamianych w ramach podejmowanych działań pomocowych.

Świadcząc pomoc, nie można zapominać o jej subsydiarnym charakterze oraz budującej zasadę pomocniczości zasadzie subsydiarnej redukcji. Polega ona na wycofaniu się ze świadczenia pomocy, kiedy jednostka wspierana zaczyna funkcjonować właściwie, a więc uzyskuje kompetencje społeczne niezbędne do samodzielnego przezwyciężania trudności. Ogromną umiejętnością podmiotów dostarczających wsparcia jest uchwycenie momentu, w którym, z uwagi na poprawę sytuacji wspieranego, należy modyfikować formy świadczonej klientowi pomocy, redukować jej zasięg tak, aby finalnie odstąpić od jej dostarczania. Zaburzenie równowagi pomiędzy podejmowanymi działaniami pomocowymi, kompensacyjnymi a aktywnością jednostki, polegające na nadmiernym wspomaganiu podmiotu wchodzącym w zakres jego kompetencji, może doprowadzić do przerzucenia odpowiedzialności za podejmowane decyzje na wspierający podmiot ${ }^{17}$. Ponadto, działania nadmiernie ingerujące - $\mathrm{w}$ ramach świadczonej pomocy - mogą spowodować pozbawienie wspieranego samodzielności, aktywności oraz wiary $\mathrm{w}$ posiadane kompetencje działania, a to skutkuje nabyciem przeświadczenia o braku wpływu na własne życie.

Jak stwierdził Martin Seligman, człowiek szybko uczy się bezradności, czyli poczucia, że jego osobista kontrola wzmocnień i wpływ na sytuację są nieefektywne ${ }^{18}$.

Świadomość znaczenia zasady pomocniczości w pracy z klientem pomocy społecznej, wspierania go w drodze do przezwyciężania różnorodnych trudności życiowych, aktywizowania, a nie tylko dostarczania pomocy, polegajacej na przyznaniu żądanego świadczenia, bez zbadania przyczyny powstania problemu i podjęcia próby jego rozwiązania wspólnie z klientem, jest zagadnieniem niezwykle istotnym $\mathrm{z}$ punktu widzenia realizacji celów pomocy społecznej. Współcześnie więc praca socjalna postrzegana jest jako oparta na wiedzy oraz wyraźnych podstawach aksjologicznych (takich jak równość i sprawiedliwość społeczna, niezbywalna godność osoby ludzkiej) „(...) praktyka przeprowadzania skutecznej zmiany na poziomie jednostki,

\footnotetext{
${ }^{16}$ I. Sierpowska, Ustawa o pomocy społecznej, s. 25.

${ }_{17}$ J. Rajewska de Mezer, Rozważania dotyczace aktywizującej roli podmiotów, s. 241.

${ }^{18}$ Por. M.E.P. Seligman, Helplessness.
} 
rodziny, grupy, społeczności lokalnej “19. W nowoczesnym podejściu do pracy socjalnej klient postrzegany jest jako posiadający własne siły i zasoby, zdolny do podejmowania decyzji dotyczacych swojego życia, mogący pełnoprawnie współpracowć w wyjściu z trudności, natomiat pracownik socjalny ma wejść $w$ rolę partnera realcji, swego rodzaju facylitatora ${ }^{20}$, osoby towarzyszącej aktywizująco w zmianie.

Tak rozumiana pomoc powinna prowadzić do wyposażnia jednostki wspieranej w kompetencje konieczne do podjecia działania samopomocowego, a tym samym do przeciwdziałania jej marginalizacji, czy ekskluzji społecznej, dzięki umożliwieniu wejścia w wyznaczone role społeczne oraz poprawnego, społecznie oczekiwanego ich odgrywania. Pojęcie roli społecznejej związane jest z pojęciem pozycji społecznej - a więc usytuowania człowieka w pewnej zbiorowości. Działaniami w zakresie wsparcia w wejście w role społeczne może być skierowanie beneficjenta na kursy zawodowe, doszkalanie, pomoc w znalezieniu miejsca zatrudnienia. Czasami wspomagany nie jest gotowy do podjęcia wyzwania polegającego na podjęciu prób zdobycia pracy, gdyż boryka się z problemami w kontaktach interpersonalnych, nie ma umiejetności konwersacji, jak i podstawowych umiejętności koniecznych w życiu społecznym. Diagnozujący problem pracownik socjalny może wówczas skierować podopiecznego do psychologa, terapeuty świadczących poradnictwo specjalistyczne, umożliwić uczestnictwo w warsztatch rozwijających kompetencje społeczne, udzielić informacji i pomóc klientowi w rozwiązaniu problemu.

Brak reakcji państwa, konstruktywnego we wsparcie w wyjściu z sytuacji problemowej, może wieść do utrwalenia się niepoprawnego sposobu funkcjonowania społecznego jednostki, czy rodziny. Skutkiem tego jest przekazywanie w międzypokoleniowym pasie transmisyjnym niepożądanych wzorów zachowań, ról społecznych, czy postaw wychowującym się w rodzinach otaczanych oparciem dzieci. Może to prowadzić do zaburzenia poprawnego przebiegu procesu socjalizacji i generowania zjawiska niedostosowania społecznego.

Problemy, w obliczu których pracownik socjalny staje wykonując swoje zadania, opierając się na zasadzie pomocniczości, pochodzą z różnych dziedzin nauki, w tym z pedagogiki, socjologii, psychologii, a także prawa. Za-

19 T. Kaźmierczak, Czy praca socjalna w Polsce jest nowoczesna? [w:] Wspótczesne wyzwania i metody pracy socjalnej, red. W. Szymczak, Lublin 2009, s. 90.

${ }^{20}$ Tamże, s. 93.

${ }^{21}$ Jak podaje B. Szacka, rolę społeczną określa się z jednej strony jako zespół praw i obowiązków związanych z daną pozycją, a z drugiej strony - jako schemat pewnego zachowania związanego z wyżej wymienioną pozycją (tzw. scenariusz roli); Zob. taże, Wprowadzenie do socjologii, Warszawa 2003, s. 144-145. 
gadnienia prawne z zakresu prawa materialnego oraz procedury stanowią istotną część pracy pracowników socjalnych i asystentów rodziny. Diagnozowanie problemu funkcjonowania jednostki, czy rodziny oraz jego analiza następuje po przeprowadzeniu wywiadu środowiskowego i zebraniu wszystkich niezbędnych do oceny sytuacji beneficjenta informacji. Właściwe skonstruowanie planu pomocowego, zmierzające do aktywizacji klienta, wskrzeszania w nim tak zwanej samopomocy, wsparcie go w uzyskaniu kompetencji do działania, wymaga szerokiej wiedzy, jak również doświadczenia. Wiedza ta obejmuje problematykę objętą przede wszystkim ustawą o pomocy społecznej w zakresie świadczeń materialnych i niematerialnych. Niestety, przepisy samej Ustawy o pomocy społecznej nie zawierają regulacji znajdujących zastosowanie we wszystkich sprawach, z którymi klient zwraca się o wsparcie do właściwego ośrodka pomocy społecznej. Właściwa interpretacja przepisów, stwierdzenie zaistnienia przesłanek udzielenia pomocy, będące wynikiem znajomości regulacji prawnych i zasad ich stosowania, pozwala na efektywne wsparcie klienta. Konieczność posiadania przez pracownika socjalnego określonego zakresu wiedzy wynika choćby z art. 119 Ustawy o pomocy społecznej. W myśl tego przepisu, do zadań pracownika socjalnego należy w szczególności:

1) prowadzenie pracy socjalnej z klientem $i$ jego rodziną;

2) dokonywanie analizy i oceny zjawisk, które powodują zapotrzebowanie na świadczenia z pomocy społecznej oraz kwalifikowanie do uzyskania tych świadczeń;

3) udzielanie informacji, wskazówek i pomocy w zakresie rozwiązywania spraw życiowych osobom, które dzięki tej pomocy będą zdolne samodzielnie rozwiązywać problemy będące przyczyną trudnej sytuacji życiowej; skuteczne posługiwanie się przepisami prawa $\mathrm{w}$ realizacji tych zadań;

4) pomoc w uzyskaniu dla osób będących w trudnej sytuacji życiowej poradnictwa dotyczącego możliwości rozwiązywania problemów i udzielania pomocy przez właściwe instytucje państwowe, samorządowe i organizacje pozarządowe oraz wspieranie $\mathrm{w}$ uzyskiwaniu pomocy;

5) udzielanie pomocy zgodnie z zasadami etyki zawodowej;

6) pobudzanie społecznej aktywności oraz inspirowanie działań samopomocowych w zaspokajaniu niezbędnych potrzeb życiowych osób, rodzin, grup i środowisk społecznych;

7) współpraca i współdziałanie z innymi specjalistami w celu przeciwdziałania oraz ograniczania patologii i skutków negatywnych zjawisk społecznych, łagodzenie skutków ubóstwa;

8) inicjowanie nowych form pomocy osobom i rodzinom znajdującym się w trudnej sytuacji życiowej oraz inspirowanie powołania instytucji świadczących usługi służące poprawie sytuacji takich osób i rodzin; 
9) współuczestniczenie w inspirowaniu, opracowaniu, wdrożeniu oraz rozwijaniu regionalnych i lokalnych programów pomocy społecznej ukierunkowanych na podniesienie jakości życia ${ }^{22}$.

Jak wynika z powyższego, wielość obszarów i płaszczyzn działania zawodowego pracownika socjalnego wymaga od niego profesjonalizmu i szerokiej interdyscyplinarnej wiedzy.

W myśl chociażby art. 119 ust. 2 Ustawy o pomocy społecznej, pracownik socjalny zobligowany jest ustawowo do udzielania osobom zgłaszającym się pełnej informacji o przysługujących im świadczeniach i dostępnych formach pomocy. Natomisat, treść art. 119 ust. 1 pkt 3 nakłada na niego obowiązek skutecznego posługiwania się przepisami prawa $\mathrm{w}$ realizacji zadań polegających na udzielaniu informacji, wskazówek i pomocy w zakresie rozwiązywania spraw życiowych osobom, które dzięki tej pomocy będą zdolne samodzielnie rozwiązywać problemy. Aby zgodnie z dyspozycją ustępu 7 omawianego artykułu właściwie i efektywnie współpracować z róźnymi specjalistami w ramach działań profilaktycznych, udzielania pomocy o charakterze interdyscyplinarnym, muszą oni dysponować wiedzą odnośnie treści szeregu aktów prawnych regulujących zasady funkcjonowania różnych instytucji i podmiotów będących bezpośrednio i pośrednio związanych z systemem pomocy społecznej.

$\mathrm{Z}$ regulacji art. 119 wynika więc obowiązek posiadania aktualnej i kompleksowej wiedzy na temat przewidzianych aktami prawnymi z zakresu pomocy społecznej rodzajów świadczeń oraz przesłanek ich nabycia. Wymaga to znajomości zarówno norm prawa administracyjnego materialnego (do którego zaliczamy prawo socjalne) ${ }^{23}$, jak i przepisów o charakterze formalnym, proceduralnym, regulujących postępowanie w sprawie nabycia świadczeń (przepisy procedury administracyjnej) ${ }^{24}$.

Najczęściej, osoba korzystająca z pomocy społecznej pobiera poza świadczeniami z pomocy społecznej również świadczenia rodzinne (zasiłek rodzinny wraz z dodatkami), świadczenie rodzicielskie, specjalny zasiłek opiekuńczy, czy świadczenie pielęgnacyjne, regulowane przepisami ustawy o świadczeniach rodzinnych ${ }^{25}$. W wielu przypadkach beneficjenci pomocy społecznej uprawnieni są także do pobierania świadczeń z funduszu alimentacyjnego ${ }^{26}$, czy dodatku mieszkaniowego ${ }^{27}$. Ustawy regulujące powyższe

22 Art. 119 ust. 1 Ustawy z 12 marca 2014 r. o pomocy społecznej.

${ }^{23}$ Szerzej I. Sierpowska, Prawo pomocy społecznej.

${ }^{24}$ Regulacje dotyczące procedury administracyjnej znajdują się w ustawie z 14 czerwca 1960 r. Kodeks postępowania administracyjnego (DzU z 2016, poz. 23 ze zm.).

${ }^{25}$ Ustawa z 28 listopada 2003 r. o świadczeniach rodzinnych (DzU z 2017, poz. 1952 ze zm.).

${ }^{26}$ Ustawa z 7 września 2007 r. o pomocy osobom uprawnionym do alimentów (DzU z 2018, poz. 554 ze zm.).

${ }^{27}$ Ustawa z 21 czerwca 2001 r. o dodatkach mieszkaniowych (DzU z 2017, poz. 180). 
zagadnienia są obszerne, wymagają znajomości innych aktów prawnych, do których treści nawiazują, nakazując analogiczne stosowanie wskazanych w nich rozwiazań. Charakteryzują się szczegółowością i odmiennościami w stanowionych przesłankach nabycia poszczególnych świadczeń. Wiele przepisów jest niejednoznacznych interpretacyjnie, co powoduje konieczność poszukiwania i posiłkowania się orzecznictwem sądowym. Czynnikiem utrudniającym wypełnianie zadania polegającego na profesjonalnym informowaniu klienta o warunkach nabycia pomocy jest ulegająca ciągłym zmianom treść przepisów, co wpływa na zaburzenie poczucia stabilności sytuacji prawnej obywatela.

Pracownik socjalny pracujący z klientem i jego rodziną musi poza wiedzą z zakresu pracy socjalnej, psychologii, pedagogiki być także zorientowany w regulacjach prawnych dotyczących wyżej wymienionych świadczeń, oraz warunków ich nabycia, aby wskazać klientowi także inne, niż wynikające tylko z Ustawy o pomocy społecznej, formy wsparcia.

Pomimo często dużego doświadczenia w pracy z tą Ustawą, uzyskanego zgodnie z jej przepisami wykształcenia zawodowego czy wyższego ${ }^{28}$, specjalizacji, uczestnictwa w szkoleniach, warsztatach, podnoszenia kwalifikacji zawodowych na kurasach specjalistycznych i studiach podyplomowych, pracownik socjalny nie posiadający wykształcenia stricte prawniczego ma problem z interpretacją wielu przepisów prawnych. Zauważyć należy, że z niejednoznacznością interpretacyjną przepisów możemy spotykać się zarówno w dziedzinie prawa socjalnego (problematyka objęta Ustawą o pomocy społecznej, Ustawą o wspieraniu rodziny i systemie pieczy zastępczej, Ustawą o świadczeniach rodzinnych), jak i przy rozwiązywaniu problemów pochodzących z innych działów prawa, z którymi beneficjent zwraca się do wspierającego go pracownika socjalnego.

Pracownik socjalny pracując z klientem ma możliwość skierowania go do świadczących specjalistyczne poradnictwo: psychologa, prawnika, czy

${ }^{28} \mathrm{~W}$ myśl art. 116 ust 1 oraz 1a Ustawy o pomocy społecznej, pracownikiem socjalnym może być osoba, która spełnia co najmniej jeden z niżej wymienionych warunków:

1) posiada dyplom ukończenia kolegium pracowników służb społecznych;

2) ukończyła studia wyższe na kierunku praca socjalna;

3) do dnia 31 grudnia 2013 r. ukończyła studia wyższe o specjalności przygotowującej do zawodu pracownika socjalnego na jednym z kierunków: pedagogika, pedagogika specjalna, politologia, polityka społeczna, psychologia, socjologia, nauki o rodzinie.

Minister właściwy do spraw zabezpieczenia społecznego, w porozumieniu z ministrem właściwym do spraw szkolnictwa wyższego, określa, w drodze rozporządzenia, wymagane umiejętności, wykaz przedmiotów, minimalny wymiar zajęć dydaktycznych oraz zakres i wymiar praktyk zawodowych dla specjalności przygotowującej do zawodu pracownika socjalnego, realizowanej w szkołach wyższych na wskazanych wyżej kierunkach, kierując się koniecznością odpowiedniego przygotowania absolwentów do wykonywania zawodu pracownika socjalnego. 
też specjalisty pracy z rodziną. Taką możliwość daje mu regulacja zawarta w przepisie art. 46 ust. 1 Ustawy o pomocy społecznej, zgodnie z którą poradnictwo specjalistyczne, w szczególności: prawne, psychologiczne i rodzinne jest świadczone osobom i rodzinom, które mają trudności lub wykazują potrzebę wsparcia $w$ rozwiązaniu swoich problemów życiowych. Ustawodawca nie dokonał $w$ wyżej cytowanym przepisie enumeratywnego wymienienia rodzajów poradnictwa. Katalog ten ma więc charakter otwarty i stanowi przykładowe wyartykułowanie dziedzin, w zakresie których następuje udzielanie pomocy poradniczej.

Poradnictwo prawne natomiast polega przede wszystkim na udzielaniu informacji o obowiązujących przepisach z zakresu prawa rodzinnego i opiekuńczego, zabezpieczenia społecznego oraz ochrony praw lokatorów. Pomimo że z redakcji przepisy art. 46 ust. 2 wynika, iż porada prawna winna być udzielona tylko $\mathrm{w}$ zakresie trzech wymienionych $\mathrm{w}$ nim dziedzin: prawa rodzinnego i opiekuńczego, prawa zabezpieczenia społecznego oraz przepisów dotyczących ochrony lokatorów, przepis ten jednak należy interpretować biorąc pod uwagę wykładnię celowościową i przyjąć, iż beneficjent ma prawo oczekiwać udzielenia mu wyjaśnień także w zakresie zagadnień znajdujących się $\mathrm{w}$ zainteresowaniu innych, niż wymienione $\mathrm{w}$ przepisie expressis verbis dziedzin.

Często z uwagi na ograniczony dostęp do osoby zajmującej się zawodowo problematyką $\mathrm{z}$ zakresu prawa (zatrudnionego $\mathrm{w}$ jednostce pomocy społecznej prawnika - radcy prawnego czy adwokata), pracownik socjalny zmuszony jest samodzielnie udzielić beneficjentowi informacji bądź porady stanowiących podstawę podjęcia przez klienta działań o charakterze samopomocowym.

Różnorodność i multiprzyczynowość sytuacji generujących problemy z właściwym funkcjonowaniem jednostki, czy rodziny, oraz duża ilość negatywnych skutków związanych z ich wystąpieniem, powoduje konieczność wielopłaszczyznowego wsparcia klienta. Trudności powoduje także określenie, jaki problem był tym pierwotnym, odpowiedzialnym za wystąpienie innych o charakterze w tórnym.

Problemy prawne wywierają często bezpośredni wpływ na sytuację osobistą, rodzinną, majątkową, finansową, czy zawodową klienta, a ich rozwiązanie może doprowadzić do poprawy funkcjonowania człowieka i jego rodziny w różnych sferach ich życia. Problemy te bardzo często dotyczą spraw z zakresu prawa rodzinnego. Są to postępowania sądowe o rozwód lub orzeczenie separacji. Licznie występują sprawy o alimenty (ich ustalenie, podwyższenie, a czasami obniżenie), i związane z nimi pytania o egzekucję komorniczą należnej renty alimentacyjnej. Problemy te dotyczą sytuacji materialnej klientów, z którą związane jest prawo do świadczeń zależnych, na przykład od nieprze- 
kraczania ustawowo określonych kryteriów dochodowych. Coraz częściej osoby objęte wsparciem proszą o pomoc we wszczęciu postępowania sądowego odnośnie uregulowania kontaktów niezamieszkującego rodzica z dzieckiem, czy ingerencję we władzę rodzicielską - poprzez jej ograniczenie lub pozbawienie drugiego rodzica. Są to problemy, które dezorganizują życie rodzinne, powodują konieczność faktycznego wykonywania władzy rodzicielskiej przez jednego z rodziców, przy ograniczaniu partycypacji w życie rodziny i dziecka drugiego. Podkreślić należy, że działania o charakterze ingerencyjnym są uzasadnione, kiedy postępowanie rodzica wobec dziecka zagraża jego dobru lub w nie bezpośrednio godzi. W wielu sytuacjach konflikt dotyczy relacji partnerskiej, a rozwód, czy separacja rodziców, i związana z nimi konieczność opuszczenia wspólnego domu przez drugiego z rodziców, jest źródłem cierpienia dla dziecka emocjonalnie związanego z obojgiem. Dziecko wymaga wówczas nie tylko skupienia na nim uwagi rodziców, ale częstokroć profesjonalnego wsparcia psychologa, czy terapeuty, nie potrafiąc samodzielnie przezwyciężyć skutków sytuacji kryzysowej w rodzinie.

W ramach problemów z zakresu prawa rodzinnego pojawiają się sprawy dotyczące faktu ustalenia pochodzenia dziecka od danego mężczyzny. Ma to istotne znaczenie dla możliwości stwierdzenia istnienia obowiązku alimentacyjnego danego mężczyzny wobec dziecka.

Problemy formalne z dziedziny prawa rodzinnego, z którymi przychodzi mierzyć się zawodowo pracownikowi socjalnemu, wiążą się z szeregiem negatywnych dla klienta skutków pozaprawnych, związanych z rozpadem rodziny, zaburzeniem relacji pomiedzy jej członkami, problemem utrzymywania więzi emocjonalnej. Rozpad rodziny jest sytuacją kryzysu dla wychowujących się w niej dzieci, które czasami w stopniu większym niż dorośli partnerzy związku potrzebują wsparcia psychologicznego i interwencji pomocowej z zewnątrz.

Wielu klientów pomocy społecznej stanowią osoby niepełnosprawne, borykające się z różnego rodzaju chorobami, nie posiadające zatrudnienia oraz prawa do świadczeń o charakterze rentowym. Dużą grupę spraw, z którymi klienci ci nie potrafią poradzić sobie sami, stanowią problemy z zakresu prawa zabezpieczenia społecznego. Wśród nich istotne miejsce zajmują kwestie dotyczące ustalania niepełnosprawności (lub stopnia niepełnosprawności), zdobycia orzeczenia o niezdolności do pracy i związanej z nim renty oraz postępowań odwoławczych w tych sprawach. Pracownik socjalny spotyka się z prośbą o pomoc w wypełnieniu i złożeniu wniosków o ustalenie stopnia niepełnosprawości, czy rentę z tytułu niezdolności do pracy. Klienci otrzymują także od organów orzekających w sprawach dotyczących niepełnosprawności decyzje odmawiające im przyznania statusu osoby niepełnosprawnej lub niezdolnej do pracy, a co z tym związane - tracą prawo do wy- 
nikających z posiadania tego statusu świadczeń. Rola pracownika socjalnego, wspomaganego przez prawnika współpracującego z danym podmiotem pomocy społecznej, polega na pomocy w sporządzeniu odwołania od orzeczenia, czy decyzji.

Następną grupę problemów, w obliczu których stają podopieczni pracowników socjalnych, stanowią sprawy z zakresu prawa pracy. W szczególności dotyczą one praw pracowniczych, przeciwdziałania dyskryminacji (ze względu na wiek, płeć, czy niepełnosprawność), bądź mobbingowi, podstaw i zasadności rozwiązywania stosunku pracy, czy sprostowania świadectwa pracy. Beneficjenci pomocy społecznej poszukują również wsparcia w rozwiązywaniu problemów wynikających z posiadania przez nich statusu osoby bezrobotnej.

Z uwagi na to, że wielu klientów ośrodków pomocy społecznej nie ma zatrudnienia i związanego z nim prawa do wynagrodzenia, oraz świadczeń rentowych czy emerytalnych, lub nie potrafi właściwie wykorzystać posiadanych, często szczupłych, środków, nie uiszczają oni należności za wynajem lokalu, czynszów i tym podobne, a co za tym idzie - toczą się wobec nich postępowania egzekucyjne i eksmisyjne. Niektórzy klienci, z uwagi na bardzo niską świadomość prawną, nie potrafią przeciwdziałać łamaniu ich praw w zakresie nieuzasadnionego podnoszenia opłat czynszowych $\mathrm{i}$ innych kosztów związanyh z eksploatacją mieszkania. Pracownik socjalny prowadzący pracę socjalną $\mathrm{z}$ klientem wspiera go także $\mathrm{w}$ zakresie tych spraw, analizując z nim umowę najmu lokalu, mediując między wynajmującym a najemcą satysfakcjonujące obie strony rozwiązanie. Wiele spraw dotyczy problemów z zakresu prawa cywilnego, bankowego i jest związanych z zaciąganymi przez klientów zobowiązaniami na podstawie umów pożyczki, czy umów kredytowych. Często nie respektują oni postanowień umowy odnośnie terminowości spłaty rat, ich wysokości, co również skutkuje wypowiadaniem im umów oraz wszczynaniem wobec nich postępowań egzekucyjnych. W wielu przypadkach klienci nie są $\mathrm{w}$ stanie zapoznać się $\mathrm{z}$ treścią umowy oraz zawartymi w niej warunkami z powodu problemów z czytaniem tekstu ze zrozumieniem oraz zaburzeniem, czasami niewykształceniem rozumowania dedukcyjnego.

Pracownicy socjalni wielokrotnie przeprowadzają rozmowy z klientami na temat niecelowości zaciągania zobowiązań w sytuacji braku dochodu lub jego niewielkiej wysokości, pozwalającej zaledwie na zaspokojenie części podstawowych potrzeb. Starają się uświadomić klientowi problem odpowiedzialności za zobowiązania $\mathrm{z}$ tego tytułu i ustrzec przed postępowaniem egzekucyjnym prowadzonym przez komornika.

Szereg kwestii wymagających wiedzy formalnej dotyczy sfery prawa karnego. Zdarza się bowiem, iż jeden z członków rodziny klientów ośrodków 
pomocy społecznej odbywa karę pozbawienia wolności lub orzeczono wobec niego kary o charakterze wolnościowym (grzywnę, czy ograniczenie wolności). Pojawiają się pytania dotyczące problemów przerwy w odbywaniu kary, warunkowego przedterminowego zwolnienia z zakładu karnego, odroczenia wykonania kary, prac wykonywanych na cele społeczne. Wyjaśnienia wymagają także problemy związane z wykonywaniem środków karnych orzekanych przez sądy obok kary.

Jedną z sytuacji stanowiących podstawę udzielania pomocy przewidzianej przez Ustawę o pomocy społecznej są trudności w przystosowaniu się do życia w środowisku otwartym osób opuszczających zakłady karne, czyli instytucje o charakterze totalnym, których celem jest resocjalizacja odbywających w nich karę pozbawienia wolności skazanych. Długotrwałe wykonywanie kary w izolacji od środowiska zewnętrznego powoduje deprywacje podstawowych potrzeb człowieka. Pobyt w zakładzie karnym skutkuje wystąpieniem prizonizacji skazanego, która utrudnia jego readaptację społeczną.

Izolacja od środowiska rodzinnego zaburza częstokroć i rozluźnia więzi rodzinne, stygmatyzuje samego skazanego na karę pozbawienia wolności, ale i jego najbliższych, którzy odczuwają wykonywanie kary wobec osadzonego w różnych sferach swojego życia ${ }^{29}$. Życie w izolacji zawęża spojrzenie na rzeczywistość, osadzony postrzega ją fragmentarycznie, często przez pryzmat poprzednich doświadczeń ${ }^{30}$.

Wsparcie byłych osadzonych opiera się też na udzieleniu informacji dotyczących możliwości uzyskania pomocy postpenitencjarnej, wskazaniu ofert pracy posiadanych przez dany ośrodek pomocy społecznej, skierowaniu do powiatowego urzędu pracy $\mathrm{w}$ celu aktywizacji zawodowej lub do organu orzekającego o niezdolności do pracy w celu uzyskania prawa do renty z tego tytułu. Wiele zagadnień z zakresu pomocy postpenitencjarnej, realizowanych przez podmioty pomocy społecznej, przybiera charakter prawny i wymaga od pracownika socjalnego specjalistycznej wiedzy prawnej, także na tym polu.

Pracownik socjalny udziela swojemu klientowi pomocy w omawianej problematyce $w$ różnym zakresie. Jest to zależne $\mathrm{z}$ jednej strony od jego wiedzy i kompetencji, z drugiej strony - od możliwości intelektualnych w zrozumieniu problemu przez klienta, jego kompetencji do podjęcia działania oraz wcześniejszych doświadczeń ze styczności z problemami o charakterze prawnym.

${ }^{29}$ J. Rajewska de Mezer, Specyfika działań z zakresu pomocy społecznej w procesie wsparcia readaptacji osób opuszczających zakład karny, [w:] Horyzonty pedagogiki resocjalizacyjnej, red. M. Muskała, A. Barczykowska, Poznań 2017, s. 490.

30 A. Kieszkowska, Wolność, wybór, odpowiedzialność i zobowiązanie przed soba i grupa w warunkach probacji, [w:] Tożsamość grupowa dewiantów a ich reintegracja społeczna, cz. II, red. W. Ambrozik, A. Kieszkowska, Kraków 2012, s. 271. 
Wsparcie udzielane klientowi przez pracowników instytucji pomocy społecznej może polegać wyłącznie na ustnym ukierunkowaniu, przez wskazanie - jakie kroki podjąć powinien beneficjent, czy do jakiego organu państwowego może zwrócić się o rozwiązanie sprawy. Jednakże, w większości przypadków, jak wynika z praktyki, wyłącznie ustne poinstruowanie klienta, co do możliwych do podjęcia działań, nie jest wystarczające. Wymaga on często pomocy w sporządzeniu pisma procesowego (wniosku, pozwów, odpowiedzi na nie), odwołania od decyzji organów odmawiających przyznania świadczeń, uprawnieńn ${ }^{31}$. Doświadczeni pracownicy socjalni mają umiejętności sporządzenia pism procesowych $\mathrm{w}$ najczęściej pojawiających się problemach (pozew o alimenty, pozew o rozwód, odwołanie od decyzji ZUS w zakresie niezdolności do pracy) oraz dysponują wzorami takowych pism, na których bazują pracując przy indywidualnej sprawie.

Poza wiedzą merytoryczną, ważne z punktu widzenia efektywności działań poradniczych są także cechy doradcy, jak jego intuicja, empatia, nastawienie do klienta, wola/chęć udzielenia pomocy oraz zastosowanie opartych na wiedzy, doświadczeniu i dostosowanych do przestrzeni, w której odbywa się proces poradniczy, metod działania ${ }^{32}$.

W sprawach szczególnie skomplikowanych, wymagających znalezienia odpowiednich regulacji prawnych, ich interpretacji (przy niejednoznaczności interpretacyjnej przepisu stanowiącego podstawę rozwiązania problemu), konieczne jest skierowanie beneficjenta do współpracującego z daną jednostką organizacyjną pomocy społecznej prawnika (np. radcy prawnego, adwokata). Poradnictwo świadczone na podstawie przepisów Ustawy o pomocy społecznej świadczone jest klientom bezpłatnie, nawet jeżeli dochód klienta przekracza określone przepisami kryterium dochodowe.

Właściwie udzielona pod względem merytorycznym informacja z zakresu (w omawianym przypadku) problemów prawnych ma istotne znaczenie dla dalszego postępowania klienta. Daje możliwość podjęcia działań zmierzających do ochrony jego praw. Wspierany uzyskuje głębszą świadomość problemu, który przy wsparciu organu pomocy społecznej stara się rozwiązać. Ważnym celem wsparcia w tej formie jest wskazanie klientowi kierunku dalszego postępowania na płaszczyźnie formalnej (przed organemi administracji, czy sądem cywilnym, administracyjnym lub karnym). Odpowiednio udzialona pomoc $\mathrm{w}$ zakresie rozwiązań prawnych zawiera w sobie

${ }^{31}$ J. Rajewska de Mezer, Rola poradnictwa specjalistycznego we wsparciu rodziny w funkcji wychowawczej, [w:] Młodzież między ochrona a ryzykiem. Wspieranie rozwoju oraz pomoc psychologicznopedagogiczna dla adolescentów i adolescentek, red. B. Jankowiak, A. Matysiak-Błaszczyk, Poznań 2017, s. 195.

${ }^{32}$ A. Weissbrot-Koziarska, Poradnictwo socjalne dla rodzin. Podręcznik akademicki, Opole 2012, s. 45 . 
elementy edukacyjne, pozwala na zapoznanie beneficjenta z procedurami działania poszczególnych organów państwa oraz rodzajami pomocy i warunkami ich nabycia. Obiektywizuje posiadany przez klienta obraz sytuacji na gruncie obowiązującego stanu prawnego pozwala poznać skutki prawne poszczególnych, zaproponowanych rozwiązań ${ }^{33}$. Co niezwykle ważne daje poczucie pewnej stabilności, przewidywalności, pozwala na uzyskanie poczucia sprawstwa, możliwości wpływu na swoje życie. Związane z rozwiązaniem danego problemu formalnego doświadczenia stają się zasobem jednostki, która nabywa w ten sposób nowe kompetencje do działania.

Poradnictwo i wsparcie o charakterze edukacyjno-informacyjnym - także $\mathrm{w}$ problematyce prawnej - zawierają się $\mathrm{w}$ działaniach $\mathrm{z}$ zakresu pracy socjalnej prowadzonej przez pracownika socjalnego z klientem.

Działania w ramach pracy socjalnej określane są jako celowe i metodyczne, co powoduje, że realizowane są wedle określonych specyficznych zasad oraz metod ${ }^{34}$. Mają charakter oddziaływań procesualnych i uporządkowanych w czasie $^{35}$. Cele tej formy pomocy realizowane są w odniesieniu zarówno do indywidualnej, jak i grupowej aktywności jednostki ludzkiej, a praca socjalna $\mathrm{z}$ beneficjentem, także przy rozwiązywaniu problemów z dziedziny prawa, ma go wesprzeć, dzięki przygotowaniu do samodzielnego przezwyciężenia trudności życiowych, z którymi nie był on w stanie poradzić sobie wykorzystując własne możliwości i zasoby. Właściwe wsparcie świadczone w ramach pracy socjalnej z klientem, jak już wspomniano, wymaga od pracownika socjalnego posiadania szerokiej wiedzy. Studia licencjackie

(...) zgodnie z minimum programowym obowiązującym na kierumku praca socjalna, powinny się wiązać $z$ przygotowaniem teoretycznym do podstawowych modeli pracy socjalnej, opartych na interdyscyplinarnej wiedzy ${ }^{36}$.

Jednakże, pojawia się często, akcentowany przez badaczy zagadnienia, problem rozdźwięku pomiędzy uzyskaną podczas studiów wiedzą akademicką a wiedzą faktycznie potrzebną i użyteczną w codziennej pracy zawodowej pracowników socjalnych, jak również kwestia dysproporcji w wykorzystaniu czasu pracy polegająca przede wszystkim na poświęcaniu go głównie na

${ }^{33}$ J. Rajewska de Mezer, Rola poradnictwa prawnego jako formy wsparcia beneficjenta pomocy społecznej, [w:] Poradnictwo. Kolejne przybliżenia, red. M. Piorunek, Torun 2011, s. 189-190.

34 K. Wódz, Praca socjalna w środowisku zamieszkania, Katowice 1998, s. 13.

35 A. Niesporek, Projekt socjalny, [w:] Praca socjalna wobec współczesnych problemów społecznych, red. S. Pawlas-Czyż, Toruń 2007, s. 75.

36 A.E. Michalska, Warunki efektywnego kształcenia pracowników socjalnych, Annales Universitatis Mariae Curie-Skłodowska, 2016, XXIX, 1, s. 9. 
czynności o charakterze administracyjnym (proceduralnym), zamiast właściwej pracy socjalnej z klientem ${ }^{37}$.

W trakcie studiów przygotowujących do wykonywania pracy pracownika socjalnego na kierunku praca socjalna lub innych kierunkach prowadzących specjalności przygotowujące do pracy w zawodzie pracownika socjalnego, w programach studiów określone są przedmioty dotyczące problematyki prawnej, a wśród nich encyklopedia prawa (przedmiot, w ramach którego omawia się elementy różnych wybranych dziedzin prawa), prawo rodzinne i opiekuńcze, prawo socjalne, prawo zabezpieczenia społecznego, czy prawo $\mathrm{w}$ pomocy społecznej ${ }^{38}$. Elementy prawa pojawiają się podczas kursów specjalizacyjnych, szkoleń i warsztatów organizowanych w ramach podnoszenia kompetencji zawodowych i kształcenia ustawicznego kadr. Zagadnienia prawne zamieszczone zostały również $\mathrm{w}$ programach studiów podyplomowych z zakresu organizacji i zarządzania pomocą społeczną. Tematyka dotycząca różnorodnych kwestii prawnych - obowiązującego stanu prawnego, jak i orzecznictwa - cieszy się dużym zainteresowaniem wśród zarówno studentów kierunku, jak i pracowników socjalnych spotykających się $\mathrm{w}$ swojej pracy na co dzień z problememi interpretacji oraz stosowania norm prawa socjalnego i dziedzin z nim powiązanych. Przy dużym zasobie wiedzy i doświadczenia, pracownicy socjalni często podkreślają potrzebę uzupełniania wiedzy $\mathrm{w}$ zakresie ulegających ciągłym zmianom regulacji prawnych, którymi posługują się $\mathrm{w}$ pracy. Zwracają uwagę na niedostateczny dostęp do profesjonalnie świadczących pomoc prawną instytucji i pracujących tam prawników. Ich pytania mają charakter specjalistyczny i świadczą o zawiłości problematyki, jak też często niejednoznaczności interpretacyjnej przepisów aktów prawnych, którymi się posługują, co utrudnia właściwe udzielenie wsparcia klientowi.

W wielu przypadkach kształcenie pracowników socjalnych w zakresie zagadnień prawnych polega na przekazywaniu im wiedzy teoretycznej, zapoznawaniu się z tekstem ustawy i omawianiu poszczególnych przepisów,

${ }^{37}$ Szerzej tamże; T. Kaźmierczak, Pracownicy socjalni, kapitał ludzki, profesjonalna praktyka, [w:] Pracownicy socjalni i praca socjalna w Polsce. Między stużbą spoteczna a urzędem, red. M. Rymsza, Warszawa 2012; M. Rymsza (red.), Pracownicy socjalni i praca socjalna w Polsce. Między stużba społeczna a urzędem, Warszawa 2012.

${ }^{38}$ Na przykład, na Wydziale Nauk Społecznych UAM w Poznaniu w programie nauczania studiów na kierunku praca socjalna znajdują się: na I roku studiów I stopnia przedmiot: Encyklopedia prawa (przedmiot, w ramach którego omawia się elementy różnych wybranych dziedzin prawa) w wymiarze 30 godzin wykładu, na III roku I stopnia: Prawo rodzinne i opiekuńcze także w wymierze 30 godzin wykładowych, natomiast na II roku studiów magisterskich na tym kierunku studenci uczestniczą w zajęciach z przedmiotu: Prawo w pomocy społecznej (wymiar 15 godzin wykładowych i 15 konwersatoriów), stanowiącym podsumowanie wiedzy z zakresu prawa niezbędnej w pracy pracownika socjalnego, socjologia.amu.edu.pl [dostęp: 12.02.2018]. 
nie popartym ćwiczeniami o charakterze praktycznym, co przy niewłaściwym zrozumieniu problemu powoduje często mylne interpretowanie i błędy w stosowaniu prawa. W procesie nauczania, według doświadczeń zawodowych autorki ${ }^{39}$, powinny znaleźć się elementy wyposażające przyszłego pracownika socjalnego $\mathrm{w}$ takie kompetencje praktyczne, jak:

- praca nad rozwiązaniem kazusów prezentujących określony problem - stan faktyczny, z jakim może spotkać się pracownik w życiu zawodowym oraz umiejętność subsumpcji;

- nauka tworzenia pism procesowych (pozwów, wniosków do sądu, odwołań od decyzji organów administracji, apelacji);

- wiedza praktyczna z zakresu procedur: administracyjnej i cywilnej, pozwalająca na właściwe, terminowe i zgodne z wymogami ustawowymi formułowanie pism w sprawach i oparte na zasadzie legalności prowadzenie postępowań;

- wiedza dotycząca zakresu uprawnień i kompetencji innych organów, instytucji, z którymi współdziała w ramach wykonywania swoich zawodowych funkcji pracownik socjalny.

Wsparciem dla pracownika socjalnego w jego pracy z klientem, ale także formą zapewnienia mu bezpieczeństwa formalnego, jest kształcenie ustawiczne, organizowanie szkoleń, seminariów, spotkań dyskusyjno-praktycznych, wymiany doświadczeń, informowanie o zmianach obowiązujących przepisów, sposobie ich interpretacji.

W świetle wielości i różnorodności problemów pochodzących z różnych dziedzin prawa, z jakimi styka się zawodowo pracownik socjalny, istotne jest także umożliwienie mu szerszego kontaktu i konsultacji ze współpracującymi z jednostkami organizacyjnymi pomocy społecznej prawnikami (radcami prawnymi, adwokatami), specjalizującymi się w prawie socjalnym, rodzinnym i opiekuńczym, prawie pracy, czy prawie zabezpieczenia społecznego. Wskazówki udzielone przez osoby zajmujące się obsługą prawną ośrodka dają pracownikowi socjalnemu konieczne dla prowadzenia sprawy informacje, ale co także istotne - poczucie bezpieczeństwa z punktu widzenia formalnego, szczególnie przy często występującej niejednoznaczności interpretacyjnej przepisów prawa i ich zmienności.

Dużą pomoc dla pracowników socjalnych może stanowić umiejętność korzystania z programów komputerowych zapewniających dostęp do tre-

${ }^{39}$ Autorka tekstu twierdzenia swe opiera na doświadczeniu kilkuletniej współpracy z podmiotami pomocy społecznej jako radca prawny prowadzący obsługę prawną ośrodka pomocy społecznej i świadczący w ramach zadań specjalistyczne poradnictwo prawne, a jednocześnie kształcąc kadrę pomocy społecznej jako wykładowca na studiach licencjackich i magisterskich na kierunku: praca socjalna oraz licznych studiach podyplomowych i kursach doskonalących dla pracowników socjalnych. 
ści obowiązujących aktów prawnych (jak np. Lex Polonica, Lex Omega, Lex Gamma). Poza aktualnym stanem prawnym, programy te dają dostęp do orzecznictwa sądów i organów administracji, tez piśmiennictwa oraz wzorów pism urzędowych. Co istotne, zawierają ujednolicone teksty aktów prawnych wraz z kompletnymi metrykami i skanami aktów prawnych opublikowanych w Dzienniku Ustaw i Monitorze Polskim od 1918 roku. Pozwalają, dzięki odpowiednim metodom wyszukiwania, niezwłocznie uzyskiwać informacje o terści danego aktu prawnego, czy konkretnego przepisu, orzecznictwie z nim związanym. Treści prezentowane w programach, o których mowa, są niezwykle przydatne przy formułowaniu i uzasadnianiu rozstrzygnięć dokonywanych $\mathrm{w}$ procedurze administracyjnej $\mathrm{w}$ formie decyzji.

Podsumowując powyższe rozważania, należy zauważyć, że pracownik socjalny poza szerokim zakresem zadań ustawowych, związanych z profilaktyką, wsparciem i akywizacją klienta pomocy społecznej, konstruowaniem, prowadzeniem celowych metodycznych działań $\mathrm{w}$ ramach pracy socjalnej (co wymaga wiedzy z dziedziny psychologii, socjologii i pedagogki), musi mieć także wiedzę formalną z zakresu przepisów obowiązującego prawa materialnego (różnych dziedzin) i procesowego. Znajomość norm prawnych dotyczących rodzajów świadczeń, przesłanek i procedur ich nabycia jest nieodzowna dla opartego na zasadzie legalności prowadzenia działania pomocowego. Dbałość bowiem o przestrzeganie reguł proceduralnych zapewnia, poza właściwym dostosowaniem formy przyznanej pomocy, efektywność działania i pozwala na unikanie sytuacji uchylenia decyzji z powodów formalnych, a nie merytorycznych. Właściwe stosowanie prawa, często oparte na wykładni celowościowej jego przepisów, powinno stanowić ramy formalne wypełniane przez działania z zakresu szeroko rozumianej pracy socjalnej z klientem, opartej na konstytucyjnej zasadzie pomocniczości oraz idei aktywizacji i pomocy do samopomocy. Prawo będzie stanowić narzędzie wspierające $\mathrm{w}$ realizacji postulatów przyświecających nowoczesnej pomocy społecznej, opartej na zasadzie pomocniczości oraz wydobywaniu i korzystaniu z potencjału osoby wspieranej, jeżeli jego treść oraz reguły obowiązywania i interpretowania będą znane udzielającym pomocy prcownikom socjalnym, a oni będą właściwie wykształceni, doszkalani i wspierani przez profesjonalistów.

\section{BIBLIOGRAFIA}

Dobek A., Zasada pomocniczości w orzecznictwie Trybunału Konstytucyjnego, Wrocławskie Studia Erazmiańskie, z. II: Państwo - koncepcje i zadania, Wrocław 2008.

Kaźmierczak T., Polityka pomocy społecznej wobec rodziny we współczesnej Polsce, [w:] Praca socjalna. Pomoc społeczna, red. J. Kwaśniewski, Katowice 1998. 
Kaźmierczak T., Czy praca socjalna w Polsce jest nowoczesna? [w:] Wspótczesne wyzwania i metody pracy socjalnej, red. W. Szymczak, Lublin 2009.

Kaźmierczak T., Pracownicy socjalni, kapitał ludzki, profesjonalna praktyka, [w:] Pracownicy socjalni i praca socjalna w Polsce. Między stużba społeczna a urzędem, red. M. Rymsza, Warszawa 2012.

Kieszkowska A., Wolność, wybór, odpowiedzialność i zobowiązanie przed sobą i grupa w warunkach probacji, [w:] Tożsamość grupowa dewiantów a ich reintegracja społeczna, cz. II, red. W. Ambrozik, A. Kieszkowska, Kraków 2012.

Konstytucja RP z 2 kwietnia 1997 r. (DzU z 1997, nr 78, poz. 483 ze zm.).

Michalska A.E., Warunki efektywnego kształcenia pracowników socjalnych, Annales Universitatis Mariae Curie-Skłodowska, 2016, XXIX, 1.

Niesporek A., Projekt socjalny, [w:] Praca socjalna wobec wspótczesnych problemów społecznych, red. S. Pawlas-Czyż, Toruń 2007.

Nitecki S., Prawo do pomocy spotecznej w polskim systemie prawnym, Warszawa 2008.

Pius XI, Encyklika o odnowieniu ustroju społecznego - Quadragesimo Anno, przekł. ks. J. Piwowarczyk, Znak, 1982, 80.

Rajewska de Mezer J., Rola poradnictwa prawnego jako formy wsparcia beneficjenta pomocy spoŁecznej, [w:] Poradnictwo. Kolejne przybliżenia, red. M. Piorunek, Torun 2011.

Rajewska de Mezer J., Rola poradnictwa specjalistycznego we wsparciu rodziny w funkcji wychowawczej, [w:] Młodzież między ochroną a ryzykiem. Wspieranie rozwoju oraz pomoc psychologiczno-pedagogiczna dla adolescentów i adolescentek, red. B. Jankowiak, A. Matysiak-Błaszczyk, Poznań 2017.

Rajewska de Mezer J., Rozważania dotyczace aktywizującej roli podmiotów systemu pomocy społecznej, [w:] Animacja w środowisku. O potrzebie kreowania działań lokalnych (teoria a praktyka społeczna), red. K. Segiet, K. Słupska, A. Tokaj, Poznań 2017.

Rajewska de Mezer J., Specyfika działań z zakresu pomocy społecznej w procesie wsparcia readaptacji osób opuszczających zakład karny, [w:] Horyzonty pedagogiki resocjalizacyjnej, red. M. Muskała, A. Barczykowska, Poznań 2017.

Rymsza M. (red.), Pracownicy socjalni i praca socjalna w Polsce. Między stużba społeczna a urzędem, Warszawa 2012.

Seligman M.E.P., Helplessness: On Depression, Development, and Death, San Francisco 1992.

Sierpowska I., Prawo pomocy społecznej, Kraków 2006.

Sierpowska I., Ustawa o pomocy społecznej. Komentarz, Warszawa 2007.

Szacka B., Wprowadzenie do socjologii, Warszawa 2003.

Ustawa z 14 czerwca 1960 r. Kodeks postępowania administracyjnego (DzU z 2016, poz. 23 ze zm.).

Ustawa z 21 czerwca 2001 r. o dodatkach mieszkaniowych (DzU z 2017, poz. 180).

Ustawa z 28 listopada 2003 r. o świadczeniach rodzinnych (DzU z 2017, poz. 1952 ze zm.).

Ustawa z 12 marca 2004 r. o pomocy społecznej (DzU z 2017, poz. 1769).

Ustawa z 7 września 2007 r. o pomocy osobom uprawnionym do alimentów (DzU z 2018, poz. 554 ze zm.).

Weissbrot-Koziarska A., Poradnictwo socjalne dla rodzin. Podręcznik akademicki, Opole 2012.

Woźniak Z., Praca socjalna a innowacje społeczne - między rutyna i zmiana, Ruch Prawniczy, Ekonomiczny i Socjologiczny, 2016, LXXVIII, 3.

Wódz K., Praca socjalna w środowisku zamieszkania, Katowice 1998.

Wyrok Wojewódzkiego Sądu Administracyjnego w Poznaniu z 14 maja 2010 r., sygn. II SA/Po 96/10, (http://orzeczenia.nsa.gov.pl) [dostęp: 10.02.2018].

Wyrok Wojewódzkiego Sądu Administracyjnego w Olsztynie z 5 lutego 2013 r., sygn. II SA/Ol 1290/12 LexPolonica nr 5149485, http://orzeczenia.nsa.gov.pl [dostęp: 10.02.2018]. 